\title{
Judges and trials in the English ecclesiastical courts
}

\author{
R. H. Helmholz
}

\section{Introduction}

This chapter examines the nature of trials in the English ecclesiastical courts, paying special attention to the role played by the judges. The sources upon which it is based are: first, the formal rules of procedural law and the commentaries upon them written by the canonists and other jurists of the European ius commune; and second, the act books and other ancillary material from the courts themselves. In accepting the invitation to contribute to this volume, it was my hope that these two sources would illuminate each other. For the most part they do, although they leave some questions unanswered and provide some answers that are ambiguous.

This chapter concentrates its attention on the period from the mid-fifteenth century to the 1640s, when the ecclesiastical courts in England were abolished, as it turned out temporarily. Throughout this period, the Church had a system of public courts, dealing with particular areas of the law, most of which were not dealt with by the courts of the common law. In England, the customary jurisdictional divide gave to the Church the right to hear causes involving marriage and divorce, defamation, testaments and probate, tithes and other church dues, religious offences like witchcraft, heresy and blasphemy, and also crimes of the flesh like fornication, adultery and pandering. ${ }^{1}$ Laity and the clergy alike were subject to this jurisdiction. No special jurisdiction ratione personae covering the clergy existed in the English courts, even though it was called for under the formal canon law, ${ }^{2}$ and this meant that trials in the courts would have been known to a significant percentage of the English population.

\section{Court organisation}

As in the Western Church generally, the English courts were organised by diocese. Each had its own set of courts. The number in any one diocese 
depended primarily on the size and the resident population, as well as the accidents of history. On the lower level, archdeacons and many other minor dignitaries also exercised ex officio jurisdiction, the term used to designate prosecutions for offences against the law of the church, and sometimes also instance jurisdiction, the term used to refer to litigation between private parties. However, the principal courts were those that every bishop held: a consistory court presided over by his appointee.

Above all of them stood the provincial courts of Canterbury and York, to which appeal lay from the diocesan tribunals. The system of judicial appeals from lower to higher courts meant that, before the Reformation, cases could be appealed from consistory courts, first to the provincial courts and then to the papal court in Rome. Afterwards, the Court of Delegates was normally the final court of appeal for England, although in fact it was a rare case that went beyond the Court of Arches in London, the principal court of appeal for the Province of Canterbury. In the Northern Province of York, where the number of dioceses was fewer and population smaller, the archbishop's court in York performed the same appellate role.

The ubiquity and the variety of these courts throughout England ought to be stressed in any study of ecclesiastical jurisdiction. Most English men and women would have lived in proximity to one or another of these courts, and litigation could thus be begun and conducted without making a lengthy trip to London or Westminster. In this sense, they were closer in nature to the secular local courts, discussed by Maureen Mulholland in her contribution to this volume, than they were to the courts of Kings Bench and Common Pleas. Litigants would not have had to wait long to appear before them. Most sessions of the ecclesiastical courts were held regularly, roughly speaking every three weeks throughout the year, and some more frequently still, except during the months of August and September. Most of the bishops' courts met in the cathedral of the diocese, usually in a special place devoted to that purpose. Sometimes, however, they met in one of the larger parish churches, probably for reasons of convenience. For example, the consistory court of Ely often met in Great St Mary's in Cambridge, where a large number of lawyers were to be found. A parochial venue was almost always true of most of the lower courts held by archdeacons, rural deans and other ecclesiastical dignitaries. Quite a few of the latter courts also perambulated on a regular schedule, seemingly in order to reach different parts of the diocese.

The president of each court was a judge, now called the chancellor but then known more often as the officialis principalis. He was served by the registrar, the man who compiled and kept the court records, and often a deputy registrar. There would always have been a staff of lawyers, called proctors, to represent the parties in civil matters, and in the larger courts there would have been several advocates, men who were expert in the law and who argued points of law for the parties. ${ }^{3}$ Less conspicuous in the records, but usually present and undoubtedly prominent in the minds of critics, would have been 
a group of apparitors or summoners, the men who served the citations and other legal process that compelled parties to appear in court. They had to be present to prove that the absentees and the contumacious had in fact been lawfully summoned.

This small group of men was all there was in the way of legal professionals. There were thus fewer subordinate officials in England than would have been present in similar ecclesiastical tribunals in many parts of the Continent. ${ }^{4}$ There was no separate group of notaries public, for example, although many English proctors would have been created notaries and done some of the work that was done elsewhere by a separate profession. There was no separate sigillator to guarantee the authenticity of documents. There was no magister testamentorum, no receptor emendarum. Most notably absent from English practice was the promotor, or procurator fiscalis, who prosecuted criminal matters in many courts on the Continent.

The ecclesiastical courts in England differed among themselves in how large a group of lawyers were authorised to practise at any one time. The numbers of active proctors and advocates were obviously much greater in London or York, for example, than in the court of, say, the archdeacon of Essex or even the bishop of Rochester. Some of the lesser courts had only three or four proctors serving within them, and one must assume that the number reflected the amount of litigation conducted. Moreover, no advocates at all were to be found in most of these lesser courts. It was, in any event, always a limited number of lawyers, and this was by choice. New proctors were admitted only upon the death or retirement of others.

A few of the consistory courts also employed an 'examiner general' to carry on the depositions of witnesses which provided the bedrock of proof in the spiritual forum. ${ }^{5}$ Some courts would also have been able to call upon the bishop's 'sequestrator' to enforce appropriate orders to take revenues of churches into the bishop's hands, although it seems unlikely that these men regularly attended court sessions. Whatever the numbers, however, the organisational structure did not differ markedly from court to court. The judge would have been seated on a cathedra, raised above the level of the rest of the personnel during court sessions. In front of him was the registrar, perhaps with his deputy, and further forward there would have been some kind of barrier. Behind it would have stood a relatively small number of proctors and their clients.

\section{Ecclesiastical trials}

What were the trials held in the consistory courts like? It has been said that the great difference between trials using the civilian procedure characteristic of the ecclesiastical courts and trials in the English common law was that the former were written, the latter oral. There is certainly truth in this characterisation. Documents were the foundation of litigation before the ecclesiastical courts. The libel, for example, was a document that laid out the elements of 
the plaintiff's case. The questions (articuli and interrogatoria) to be put to the witnesses were, likewise, written out in advance. The testimony of witnesses was taken out of court, reduced to writing by the examiner and submitted to the judge for his own evaluation. A judge would not necessarily interrogate or even see a witness in person. The sentence too was a formal written document and, by the fifteenth century at the latest, each side had to produce its own sentence for use by the judge. The judge subscribed the sentence that accorded with his decision in the cause - this was the so-called Lecta et lata subscription - and promulgated it by reading it aloud in a formal session of the court. All these documents have survived in considerable numbers, together with a number of other written documents such as constitutions of proctors, sentences of excommunication, formal caveats and, of course, the act books themselves. They are the basis for our knowledge of what happened in litigation. This meant that court sessions can be described as meetings designed to receive the documents, with the real work of the court taking place outside the sessions of the courts themselves. This is the legitimate starting point for understanding the nature of an ecclesiastical trial. It contrasts markedly with the oral nature of the common law trials depicted, for example, in Daniel Klerman's and Anthony Musson's contributions to this volume.

However true this generalisation is as an overall matter, it is also too broad. It would be a mistake to take it for the full story. For one thing, it can give the impression that trials were secret. On the contrary, the holding of an ecclesiastical court was a public event. It was not conducted behind closed doors or simply by the exchange of papers between the parties and the judge. This openness is one reason that ecclesiastical jurisdiction would have been familiar to many men and women in England, even those with no particular interest in the canon law.

In at least five specific ways, the focus on the written documents used by the courts can give a misleading impression of the reality. First, although documents were the foundation of court procedure and were in fact handed to the court officials, there was also a good deal of speech that accompanied them. Some of it was purely formal in nature, used to introduce or to demand the introduction of documents. The treatise known as Actor et Reus, commonly found in archives throughout England, recorded the various stages of this colloquy and the dialogues found in it were used in practice. 'My lord', a proctor would say, 'I pray that a term should be assigned to me to propound a libel in due form of law.' The judge: 'We assign the next [term] to you for the purpose of introducing your libel, and to the adverse party to receive it.' The proctor: 'My lord, I pray that your lordship will admonish [the defendant] to appear in each and every session up until the end of the cause. ${ }^{6}$ So it went through to the end of the session.

This court dialogue would have been said in Latin. For some reason the English courts retained Latin for everyday usage in the courts after it had been discarded in favour of the vernacular in most parts of the Continent. The 
language used was, however, more than simply the picturesque formalism it now appears to have been. If a proctor failed to make a prayer or an objection at the proper time and in the proper form, the law held that the right to do so was waived. No doubt exceptions were made in practice, since there were excuses available under the law for most formal errors, but the law on the point must explain the widespread adherence to verbal formality that is so conspicuous in the records.

Second, the predominance of writing did not characterise office causes the disciplinary cases brought against a man or woman for violation of the Church's laws. Typical examples would be prosecutions for adultery or failure to attend one's parish church. In them, the procedure was predominantly oral, although sentences of excommunication (where necessary) were supposed to be issued in writing as well. The oral nature of these trials was an inevitable result of the canon law itself, because, as in the English common law, defendants in criminal cases could not be represented by a lawyer at all, except if a question of interpreting the law arose, in which case resort to counsel was allowed. Again, as in the common law, recourse to lawyers seldom happened in criminal practice. Documents were therefore rarely used in ex officio matters. Most defendants could not have read them. The charge was made aloud and in the vernacular, the oaths taken similarly and the assignment of penance and negotiation about it all done orally. The records contain a mixture of formulaic Latin and common English as a result. As with the royal court plea rolls, the formal nature of the records conceals a considerable amount of discussion about the determination of criminal cases.

Third, virtually any of the documents could be omitted in practice. The ordo iuris was not a strait jacket. Summary procedure was authorised under the medieval canon law, and it made a difference in practice. ${ }^{7}$ It permitted omission of all but the essential steps required to meet canonical standards of due process. By the fifteenth century, for example, the libel was almost always combined with the articles and positions into the same document. Arbitration could be used, and in fact was often assigned by judges. Where a party had introduced all his witnesses in one session, there was no need for the other two provided in the law and they were often waived in practice. All these abbreviated the trial process and dispensed with the need of some of the documents that would otherwise have been required for a trial.

Negotiation about how to proceed - since the consent of the parties might be required - of course meant that the trials were less dependent upon documents and, indeed, more informal than they otherwise would have been. In fact, the records show that many of the instance causes were disposed of without much more than oral statements by each party. ${ }^{8}$ Many of the causes brought for 'breach of faith', for example, by which the church enforced contracts entered into together with a sworn promise to pay, were dealt with very briefly and apparently on the basis of oral statements of claim and oral responses by the parties or their proctors. ${ }^{9}$ 
Fourth, it appears that when a case called for argument about the law, this too might be done orally as well as by documentary submission. In an account of a London case from the sixteenth century, for example, the advocates for the two parties are recorded as speaking one after another, quite shortly and in answer to the point just made by the other advocate. ${ }^{10}$ Citations to learned authorities from the ius commune were given and discussed by the advocates in making their argument. In other words, there was a back and forth dialogue that must have been oral, because it was too brief and spontaneous to have been part of a considered written form. The participation by advocates was thus more like a Year Book discussion in the common law (although without equivalent participation by the judges) than it was a written document to be submitted for consideration by the court.

Finally, despite the formality of the records and what can be called the initial pleading, there was a fair amount of other comment in the consistory courts and some just plain chatter. A fifteenth-century York case mentioned by the way that, "The said official and the proctors were speaking sometimes in Latin, sometimes in English. ${ }^{11}$ The records regularly describe the presence of people in the courts 'in a copious multitude'. Although the phrase is formulaic, it corresponds with other evidence about the people who were present in the courts. Occasionally, the records speak of outbursts from the litigants, perhaps naturally enough when a decision went against them. Appeals could be taken viva voce under the law, and they were, in fact, so taken. Moreover, satires written against the ecclesiastical courts, from the fourteenth century to the seventeenth, depicted them as less than sedate. Proctors shouted, one asserted, "not so much in order to be heard by the judge, as to keep up the noise'. ${ }^{12}$ No doubt there was some exaggeration in the description, but it would not have been effective as satire if there were no truth whatsoever to it. ${ }^{13} \mathrm{We}$ must not imagine the typical meeting of a consistory court as a noiseless affair in which only formal documents and language were used, despite the famous depiction of Doctors' Commons by Charles Dickens. ${ }^{14}$

\section{Role of the judge in the trials}

My second subject is the role of the judges in litigation. Here, the normal starting point has been and remains a contrast between the judges of the common law courts and those within the civilian traditions. Although they were impressive to see and their intervention with juries could be decisive, common law judges came to trials ignorant of the nature of the cases. They were referees, if you like, between the two opposing counsel in civil cases, between a defendant and the victim or other prosecuting party in criminal cases. Juries decided who won or lost. By contrast, under the ius commune the role of a judge was far from that of a referee or spectator. The procedure was under his control and he was expected to take an active role in the investigation of facts and in moving trials ahead. ${ }^{15}$ Issuance of the definitive sentence in any event lay with him, not with a jury, and he had the duty to make 
certain it was correct. There is also a good deal of truth in this widely accepted characterisation. The ultimate responsibility of decision rested upon the civilian judges who were required to review and evaluate the evidence presented by witnesses produced by the parties.

The records show that they fulfilled this responsibility in fact. Although each side submitted draft sentences, as noted above, it was up to the judges to decide between them. It is particularly noteworthy that alterations were often made to them in the course of bringing a trial to its close. Perhaps there were negotiations over the extent of liability and the wording of the sentence. However, the authoritative role of the judges appears on the sentences themselves - mostly in deletions from the wording and substitutions made above the line. This evidence demonstrates that the judges were not bound by a 'take one or the other' kind of system as one might suspect from the way in which sentences were submitted by the parties. The judges merely put the financial burden of having the sentences written out onto someone else.

As was true for the documentary nature of procedure, the 'model' of judicial activism and professional expertise taken from manuals of Continental procedure is too simple. Perhaps there is even something slightly misleading about it as a description of what went on in the English ecclesiastical courts. There were points at which the role of judges in the ecclesiastical courts can be more accurately likened to that of judges in a common law court. I know of no contemporary who made the comparison, though some observers did make a record of what the ecclesiastical court judges did in performing their role at trial.

First, the 'activist model' overestimates, by a large margin, the investigative resources at the disposal of the judges in the English spiritual courts. In truth, they had almost none. As noted above, the promotor, the agent employed by judges to investigate criminal matters and to conduct prosecutions in the name of the courts in many parts of the Continent, did not exist in the English ecclesiastical tribunals. ${ }^{16}$ If an English judge wished to promote ex officio proceedings - and this did occasionally happen - he had to choose from among the existing proctors attached to his court to have the task done. ${ }^{17}$ The summoners were also under his jurisdiction, but they had no legal training. Their formal responsibilities were limited to citing parties and (probably) reporting the public fame against individuals they had accumulated in carrying out that task. They would probably not have been thought suitable and the records have produced no examples where they were chosen to act as prosecutors. And, apart from the proctors, there was simply no one else.

From this paucity in personnel came a reliance on laymen, typically in the procedure of presentment by the churchwardens and 'questmen' of each parish. Laymen were chosen for a yearly term and, by the fifteenth century at the latest, churchwardens were required to answer a series of articles about what was amiss in the parish. Had the church fabric been neglected? Were the church services being performed? Were there notorious evil livers in the 
parish? And so forth. It was on the basis of answers provided by these laymen that most prosecutions were begun. This was, of course, inquisitorial procedure in a sense. It was conducted in the name of the court, not that of private accusers. The questions were drafted by professionals, but it was a far cry from an inquisition run by a group of trained jurists and their agents. As was true in the system of criminal prosecution in the English common law, much was left to amateurs.

Second, the 'activist model' does not fit the normal pattern of actual judicial attendance in the courts. The judges were too often absent for them to have fully performed the duties of an investigating magistrate in the civilian tradition. Francis Clerke, the London proctor who wrote a treatise on the ecclesiastical courts in the capital, remarked that the Dean of the Court of Arches, the chief civilian dignitary and judge of the highest ecclesiastical court in England, was so often occupied with diplomatic missions abroad, that he was not often in the court over which he nominally presided..$^{18}$ So spare is Clerke's description that it is impossible to know whether he meant this as a criticism of judicial conduct or not. At any rate, he did describe what one might call absenteeism from this high post.

The same absenteeism occurred among many of England's ecclesiastical court judges. For example, from the autumn of 1598 to the same time the next year, the consistory court of the diocese of Exeter was presided over by five different judges. ${ }^{19}$ It met quite often, though sometimes for the hearing of only one or two causes, but the same judge did not always preside at consecutive sessions. It was literally true that litigants could not have been sure which judge to expect on their next appearance. ${ }^{20}$ If the judges had had a strong group of lawyers serving under them, such absenteeism might not have had any effect on their ability to carry out the duties of an investigating magistrate. However, such a 'staff' is exactly what they lacked. There was the registrar and sometimes a deputy registrar, but, apart from the proctors, there was no one else upon whom to call.

Third, the judges in the ecclesiastical courts had neither the cohesive judicial institutions nor the ability to shape legal doctrine that their common law counterparts enjoyed. Such a role in the formulation of doctrine was not, to be sure, any part of the traditions of the ius commune and I do not mean to suggest any divergence between theory and practice here. Nevertheless, it is worthy of note that until the organisation of Doctors' Commons early in the sixteenth century, there was no institution like the Inns of Court in London around which judicial opinion and discussion of law and practice in the courts could coalesce. The intellectual centre of gravity in the civilian system was the university, not the courtroom, and so it remained throughout this period. In terms of the trial, this meant that the activity of the judges and the courts would not be the central focus of attention or legal development.

No equivalent to the medieval Year Books was found in the ecclesiastical system, and there were few case reports in the sixteenth and seventeenth 
centuries (although there were some), a time when the number of reports of common law cases exploded. When change in legal practice in the ecclesiastical forum occurred - and it did occur - it was likely to have been the work of commentators, working within university faculties or as commentators on the law. Either such commentators, or else pressure from without exerted by writs of prohibition, created the most significant changes in spiritual court practice over the years. To this extent, what the judges in the ecclesiastical courts did in the cases that came before them was less consequential than what the judges did within the traditions of the English common law. William Lyndwood, although Dean of Arches and hence the most important ecclesiastical judge in England, made his mark as the authoritative commentator on the English provincial constitutions, not as a judge. ${ }^{21}$

\section{The judges: training and performance}

My third subject is the professional quality of judges in the English ecclesiastical courts. Unfortunately we have no satisfactory way of evaluating that conduct overall and perhaps the best course would be simply to confess to an ignorance that is unlikely to be overcome. ${ }^{22}$ Moreover, on some matters where more information could be obtained, such as their relations with common lawyers or their familiarity with the vast literature of the ius commune, we still know too little to be able to speak with confidence. However, incidental information already unearthed from the court records and the accessibility of academic comment on the subject, makes it possible to venture three statements about the quality of the work by the judges who conducted the trials in ecclesiastical courts.

First, there is the question of their formal qualifications. If we examine the pages of the Summa aurea of Hostiensis (d. 1271), ${ }^{23}$ one of the most famous and accessible of the academic commentators on the medieval canon law, in search of the qualifications required of judges, we find five listed:

1 Condition. Judges could not be of servile condition.

2 Sex. Women could not hold the office.

3 Discretion. Judges must be compos mentis.

4 Age. Judges must be at least twenty years old.

5 Fame. Judges must not be excommunicated or notorious heretics.

It is not a long list. The number of requirements for judging that might have been mentioned but were not, may stand out more prominently than the requirements that were. The exclusions of women and the unfree are what one expects for the Middle Ages and, apart from them, it does not appear that the formal disqualifications were particularly onerous. It is noteworthy that neither holy orders nor a university education was required according to this thirteenth-century author's review of the texts of the Corpus iuris canonici. Although the canon law elsewhere excluded laymen from taking cognisance 
over spiritualia, a prohibition that would have excluded the possibility of laymen judging some, but not all, of the causes that came before the ecclesiastical courts in England. ${ }^{24}$ The formal canon law also excluded inferiors from judging their superiors and, under one understanding, this too might have required that judges be in holy orders when cases involving the clergy came before them. ${ }^{25}$ However, no specific legal training is found among the requirements for judicial office. No requirement of having passed an examination appears and the age limit, to put it mildly, would have excluded very few men from taking a judicial seat. It was only provincial legislation in England that required advocates (and therefore judges) to have attended university lectures in the law and to have taken a degree. ${ }^{26}$

What was the situation in fact? We can say little about many things, the age of judges, for example. Judging by women was what might be called a 'non-issue'. But some things we can say. Almost all the judges before the Reformation seem to have been clerics and most, but not all, of the pre-1640 judges seem to have been university graduates in law. ${ }^{27}$ A Tudor statute allowed laymen and married men to exercise spiritual jurisdiction if they held a doctorate in civil law, ${ }^{28}$ and it seems eventually to have become the rule that only laymen so trained could act as judges. The principal exception to it was that the holder of the ecclesiastical office, a bishop or an archdeacon, could himself exercise jurisdiction if he chose, and this sometimes happened in practice. If it had not indeed been true during the thirteenth century, the status of university graduate came to be required for acting regularly as a judge in the ecclesiastical forum. It is true that on occasion men who held degrees in theology, sometimes even only the M.A., were appointed to act as surrogates to the principal judges in the spiritual courts, and sometimes these men acted as judges for considerable lengths of time. But these were exceptions. For the most part, acting as a judge in an ecclesiastical court was a 'career path' down which many graduates of the law faculties at Oxford and Cambridge passed. ${ }^{29}$

Second, there is the question of the fees paid to the justice and the attendant question of judicial integrity. Like many office-holders in the Ancien Regime, the judges of England's ecclesiastical courts depended upon court fees for their basic incomes. And the records of individual trials that were fully recorded, customarily included the payment of court fees, of which judges took a share. ${ }^{30}$ Litigants paid for libels, for commissions to examine witnesses, for sentences, for documents of appeal; indeed they paid for all the paper produced during trials. Part of the money paid for these items went to the judges. Such fees were not necessarily illegal under the medieval ius commune. ${ }^{31}$ It was a question of whether or not they constituted bribery and would pervert the course of justice, though some critics regarded the line as too thin to be workable and therefore one that was not worthy of respect. ${ }^{32}$

It is also true that there were checks under the law designed to prevent bribery and partiality. The prohibitions against corruption were oft stated in 
the law and the oaths ecclesiastical lawyers were obliged to take routinely would have reminded them of their professional responsibilities. ${ }^{33}$ No canonist endorsed more than the taking of a 'moderate sum' for expenses on the part of court officials, and the ius commune provided no blanket immunity from liability or prosecution to its judges. They might have been proceeded against for deliberate error or peculation. If they asserted jurisdiction when they possessed none, their acts were a nullity in law. And, of course, it is important to remember that their judicial actions were always subject to appeal to a higher court to an extent those of common law judges were not. These protective devices must have caught some takers of bribes and may have frightened others into compliance with the law.

Nonetheless, the continuing criticism of the ecclesiastical court system as venal in nature cannot have been altogether mistaken. Although much of it was directed against the proctors and the summoners attached to the courts, some of the blame (if that is the right word) must be laid at the door of the judges. One of the more unattractive features of the system was that in $e x$ officio cases, defendants were obliged to pay court fees even if they were (as we would say) acquitted. ${ }^{34}$ The fees mounted up. They made many judges wealthy. It was considered surprising and worthy of remark, for example, that Sir Daniel Dun, Dean of Arches between 1598 and 1616, was not a rich man when he died. Virtually every matter treated in the courts in which Dun took part, ended in a payment being assessed against the parties. We may say, if we like, that the ecclesiastical courts shared this characteristic with virtually every court system in medieval and early modern Europe. And it is true that we have not wholly solved the problem today. Still, these defences should not cause us to overlook the important part that 'revenue raising' played in early trials in the ecclesiastical forum.

Third, the granting of considerable discretion to judges under the ius commune is worth noting because of the decisive effect it had on the conduct of many trials. Its endorsement in the texts must explain some of the apparent variations (and even inconsistencies) in procedure that are found in contemporary act books. For instance, excommunication for contumacy was not automatic in the ecclesiastical courts; it lay in the discretion of the judges. ${ }^{35}$ Some of the practices that led to criticism levelled at the judges, as in allowing too easy commutation of penance in return for the payment of money, were endorsed within the canon law itself. They were within the discretion of the presiding officer, who was directed to take account of all the relevant factors. The judges would have defended their actions by citing the discretion they were supposed to exercise under the law.

Legal historians have probably not yet paid enough attention to the existence and extent of discretion that was commonly vested in medieval judges. It was crucial for the conduct of trials. In comparison with legal rules, however, it is harder to talk about the actual exercise of discretion. By the nature of the concept, elaboration and satisfactory generalisation elude historians. 
However, the commentators of the ius commune commented frequently that matters had, in the end, to be left 'to the discretion of a good judge', ${ }^{36}$ and on this point the evidence of the records, and that of the commentaries, are at one. For example, the number of compurgators assigned in compurgation was left for the judge to decide. So was the pace of litigation. Reliance on judicial discretion in these matters is obviously what happened in practice, for the records repeatedly show variation and choice on the part of those in charge. Even the weight assigned to particular evidence was left largely to judicial evaluation, although again there were limits and many rules for guidance of judges contained in treatises like the huge treatise on the law of proof by Mascardus. ${ }^{37}$ W. G. Naphy's contribution to this volume is suggestive of its importance in the evaluation of criminal conduct in other legal arenas, and it is suggestive for the courts of the Church as well. The ius commune set its face against any requirement that judges explain their reasons in giving sentences, ${ }^{38}$ and that too was a measure of the considerable discretion given to them under the existing law.

\section{Conclusion}

Our knowledge of trials in the ecclesiastical courts before 1640 and of the role in judges in conducting them is imperfect. We do not know much, for example, about how long most trials lasted. We do not even know whether it is correct, strictly speaking, to use the modern term 'trial' to describe proceedings before the courts of the church. Much of the procedure was purely formal in character and some of the most important decisions, like the negotiations over the wording of each sentence, were made away from the public record. There is a real distance between what happened in the ecclesiastical courts and what we commonly think of as a trial. Added to this uncertainty is the difficulty caused by the physical disappearance of the courts where ecclesiastical trials once took place. Only in Chester cathedral has a consistory court physically outlasted the disappearance of the greater part of ecclesiastical jurisdiction during the nineteenth century. Depictions of the courts in action are also few and far between. ${ }^{39}$ Perhaps more could be done to find them, but so far no one has made a systematic effort.

Despite gaps in the surviving evidence, much can be recovered, and it appears that these ecclesiastical proceedings fit comfortably within the definition of a trial given by Joseph Jaconelli at the outset of this volume. Proceedings were open. Trials were public events. They were available to all whose claims (or offences) fitted within the division of jurisdiction that prevailed in England. They were in no sense the exclusive preserve of the clergy. Proceedings in them followed the rules set down by the sophisticated procedural system of the European ius commune, although this system always left room for many adjustments in customary practice. The ecclesiastical courts were presided over by judges trained in the law at the universities, men who were 
following a recognised career path. It will not do, of course, to make these courts into ideals of justice or to describe their judges as paragons of impartiality. Both have attracted criticism in every period of their existence. ${ }^{40}$ The early modern and medieval courts continue to do so among historians today. ${ }^{41}$ No doubt not all of the criticism is misplaced, but it is fair to conclude that proceedings held before the English ecclesiastical courts, were not 'Kafkaesque' perversions of what trials should be.

\section{Notes}

1 For general accounts of the court organisation, see A. H. Thompson, The English Clergy and Their Organization in the Later Middle Ages (Oxford, 1947), pp. 40-71: W. Stubbs, 'Report on Ecclesiastical Courts, 1883', Historical Appendix No. I to Vol. I (Parliamentary Papers, 1883, Vol. 24). For specific dioceses, see B. Woodcock, Medieval Ecclesiastical Courts in the Diocese of Canterbury (Oxford, 1952), pp. 6-29; R. A. Marchant, The Church Under Law: Justice, Administration, and Discipline in the Diocese of York, 1560-1640 (Cambridge, 1969); R. M. Haines, The Administration of the Diocese of Worcester in the First Half of the Fourteenth Century (London, 1965), pp. 104-14; C. A. Ritchie, The Ecclesiastical Courts of York (Arbroath, 1956); M. Aston, Thomas Arundel, A Study of Church Life in the Reign of Richard II (Oxford, 1967), pp. 53-82; F. S. Hockaday, "The Consistory Court of the Diocese of Gloucester', Transactions of the Bristol and Gloucestershire Archaeological Society, 46 (1924), 195-287.

2 An obvious exception to the rule that jurisdiction was not based upon personal status in England was the jurisdiction of the university courts; see, e.g., A. Shepard, 'Legal learning and the Cambridge University courts, c. 1560-1640', Journal of Legal History, 19 (1998), 62-74.

3 For an overview of the profession, with references to earlier literature, see R. O'Day, The Professions in Early Modern England, 1450-1800. Servants of the Commonweal (Harlow, 2000), pp. 151-61, and from a different perspective, D. R. Coquillette, The Civilian Writers of Doctors' Commons, London (Berlin, 1988), pp. 22-44.

4 Compare the situation in France, described in A. Lefebvre-Teillard, Les Officialités à la veille du Concile de Trente (Paris, 1973), pp. 33-8, and P. Fournier, Les Officialités au Moyen-Age (Paris, 1880), pp. 29-31.

5 E.g., Mr Richard Burgh was styled examiner general in a York Act book (1417): Borthwick Institute of Historical Research (hereinafter BI), Cons.AB.1, fol. 50.

6 See, e.g., Cambridge University Library, MS. Dd.10.36 (late sixteenth-century formulary), fol. 29 r.-V., containing a simple version of the dialogue.

7 See Clem. 5.11.2; 2.1.1; see also R. H. Helmholz, Marriage Litigation in Medieval England (Cambridge, 1974), pp. 120-2.

8 This was not unlawful; see gl. ord. AD X 2.3 .1 s. v. libellum reclamationis.

9 See Woodcock, Medieval Ecclesiastical Courts, pp. 84, 89-92.

10 Doyle v. Waynman, Bodleian Library Oxford, Tanner MS. 280, fols 307-12.

11 BI, CP.F 132 (1421).

12 See The Proctor and the Parator (place of publication unknown, 1641). No pagination. 
13 This was also a European phenomenon; see A. Steins, 'Der ordentliche Zivilprozeß nach den Offizialatsstatuten', in Zeitschrift für Rechtsgeschichte, Kanonistische Abteilung, 59 (1973), 190-262, at, 201.

14 David Copperfield (Penguin edition) (Harmondsworth, 1966. First edition, 1850), p. 330: 'such a cosey, dosey, old fashioned, time-forgotten, sleepy-headed little family party'.

15 See, e.g., P. Stein, Roman Law in European History (Cambridge, 1999), p. 59; P. Ourliac, 'L'Office du juge dans le droit canonique classique', in Mélanges offerts à Pierre Hébraud (Toulouse, 1982), p. 638.

16 R. M. Wunderli, London Church Courts and Society on the Eve of the Reformation (Cambridge, Massachusetts, 1981), p. 37.

17 E.g., Ex officio contra Mawger and Mawger (Diocese of York 1599), BI, CP.G.3048, brought for sexual relations and marrying outside of the church. William Fethergill, one of the court proctors, was assigned as the promotor of the cause.

18 Francis Clerke, Praxis in curiis ecclesiasticis, tit. 2 (London, 1684), pp. 4-5. The work was written in the 1590 s and circulated widely in manuscript before its publication.

19 Taken from Devon Record Office, Exeter, MS. Act book CC 784C; the judges were Matthew Sutcliffe, LL. D., Richard Rutter, M. A., Nicholaus Wyatt, LL. B., Evan Morrice, LL. D. and Edward Peard, LL. B. The number of their appearances as judge recorded in the Act book was, respectively, eleven, five, five, forty-six and three. The Commissary court of London between 24 November 1599 and 22 March 1600, met before five judges, Thomas Ridley, LL. D., Thomas Pope, LL. D., John Amy, LL. D., Thomas Crompson, LL. D., and Edward Burton, M. A. See London Guildhall, MS. Act book 9064/15, fols 21-42v, but the first two were by far the most frequent. The consistory court of Ely meeting in Great St Mary's, Cambridge between April 1628 and April of the next year, was presided over by four different judges, Thomas Eden, LL. D., the official principal, and three surrogates, Robert King, M. A., George Eden, M. A., and Thomas Lake, M. A. See Cambridge University Library, EDR D/2/42, fols 1-160. On the other hand, in the Canterbury commissary court for 1475, John Parmenter, Leg. Lic., was the only judge recorded as having acted. See Canterbury Cathedral Archives, MS. Act book Y.1.12, fols 44-111.

$20 \mathrm{BI} \mathrm{C/C/AB.3,} \mathrm{fol.} 41$ (1531), the officialis principalis delegated four different men to act as judges in his stead during his absence from the court: Henry Barbet, LL. D., Thomas Fox, Thomas Marsar, and John Altman.

21 On Lyndwood, see B. E. Ferme, Canon Law in Late Medieval England: A Study of William Lyndwood's 'Provinciale' with particular reference to Testamentary Law (Rome, 1996).

22 Even a list of the men who served as judges in the consistory courts is to be greatly desired. None exists, although the very top of the profession, the advocates and judges in London, has been well served; see B. Levack, The Civil Lawyers in England, 1603-1641: A Political Study (Oxford, 1973) and G. D. Squibb, Doctors' Commons: A History of the College of Advocates and Doctors of Law (Oxford, 1977).

23 Henricus de Segusio (Hostiensis), Summa aurea (Venice, 1581), Lib. I, tit. De officio ordinarii, no. 2.

24 Ibid., X 2.1.2. Panormitanus understood this as meaning that laymen could exercise jurisdiction in such cases only if the power was committed to them by the pope. See his Commentaria in libros Decretalium (Lyons, 1517) AD X 1.6.43, no. 4. 
25 C. 2. q. 7 c. 10.

26 See Council of Lambeth (1281), in F. M. Powicke and C. R. Cheney (eds), Councils \& Synods with other Documents relating to the English Church (2 vols, Oxford, 1964). II (AD 1205-1313), pp. 917-18.

27 E. Nys, Le Droit romain, le droit des gens et le Collège des Docteurs en droit civil (Brussels, 1910) p. 105.

2837 Hen. VIII, c. 17 (1545).

29 See A. L. Browne, 'The medieval officials-principal of Rochester', Archaeologia Cantiana, 53 (1940), pp. 29-61. See generally, P. Brand, The Origins of the English Legal Profession (Oxford 1992), pp. 145-6.

30 See Woodcock, Medieval Ecclesiastical Courts, pp. 136-7; R. A. Marchant, The Church under the Law: Justice, Administration and Discipline in the Diocese of York, 15601640 (Cambridge, 1969), p. 246.

31 See, e.g., Panormitanus, Commentaria, AD X 3.1.10, no. 10; William Durantis, Speculum iudiciale (Basel, 1575, repr. Aachen, 1975), Lib. 4, Pt. 4, tit. De magistris.

32 See, e.g., Dante, The Divine Comedy: Paradiso, Canto 9, lines 127-35, (ed.) C. S. Singleton (Princeton, New Jersey, 1975), pp. 102-03. See generally, J. A. Yunck, The Lineage of Lady Meed: The Development of Medieval Venality Satire (Notre Dame, Indiana, 1963).

33 See Brand, Origins, pp. 152-4; J. A. Brundage, 'The medieval advocate's profession', Law and History Review, 6 (1988), 439-64.

34 See, e.g., G. R. Quaife, Wanton Wenches and Wayward Wives: Peasants and Illicit Sex in Early Seventeenth Century England (New Brunswick, New Jersey, 1979), p. 196.

35 Noted, e.g., in British Library MS. Harl. 3190 (seventeenth-century account of civil law in England), fol. 31: 'If anyone fails to appear when summoned to judgment, he shall be subject to excommunication at the discretion of the judge (Si quis in iudicium vocatus non venerit pro arbitrio iudicis est excommunicandus).'

36 See, e.g., gl. ord. AD Sext 1.3.11, s.v. paucis; and see generally R. M. Fraher, 'Conviction according to conscience: the medieval jurists' debate concerning judicial discretion and the law of proof', Law and History Review, 7 (1989), 32-40.

37 Josephus Mascardus (d. 1588), Conclusiones probationum omnium quae in utroque foro quotidie versantur (Frankfurt, 1593).

38 See $\mathrm{P}$. Godding, 'Jurisprudence et motivation des sentences, du moyen âge à la fin $\mathrm{du} 18^{\mathrm{e}}$ siècle', in C. Perelman and P. Foriers (eds), La motivation des décisions de justice (Brussels, 1978), pp. 37-67, esp. pp. 42-50; A. Wijffels, 'Le Juge et le jugement dans la tradition du ius commune européen', in R. Jacob (ed.) Le juge et le jugement dans les traditions juridiques européennes (Paris, 1996), pp. 167-79.

39 That found as the frontispiece in Squibb, Doctors' Commons, p. ii, taken from R. Ackermann, Microcosm of London (1808), has been much used; it depicts a more formal institution than most diocesan courts would have been.

40 See, e.g., M. Haren, Sin and Society in Fourteenth-Century England: A Study of the Memoriale Presbiterorum (Oxford, 2000), pp. 14-16.

41 See, e.g., G. R. Elton, The Tudor Constitution (second edition, Cambridge, 1982), pp. 218-21: 'fear and dislike' of the courts; P. Williams, The Tudor Regime (Oxford, 1979), pp. 259-62: ‘weak and feeble machinery'. 